Discussion Paper No. 11-060

\title{
General Knowledge About Climate Change, Factors Influencing Risk Perception and Willingness to Insure
}

Claas Menny, Daniel Osberghaus, Max Pohl, and Ute Werner

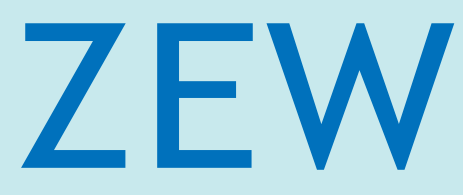

Zentrum für Europäische Wirtschaftsforschung $\mathrm{GmbH}$ Centre for European Economic Research 
Discussion Paper No. 11-060

\title{
General Knowledge About Climate Change, Factors Influencing Risk Perception and Willingness to Insure
}

\author{
Claas Menny, Daniel Osberghaus, \\ Max Pohl, and Ute Werner
}

Download this ZEW Discussion Paper from our ftp server:

http://ftp.zew.de/pub/zew-docs/dp/dp11060.pdf

Die Discussion Papers dienen einer möglichst schnellen Verbreitung von neueren Forschungsarbeiten des ZEW. Die Beiträge liegen in alleiniger Verantwortung der Autoren und stellen nicht notwendigerweise die Meinung des ZEW dar.

Discussion Papers are intended to make results of ZEW research promptly available to other economists in order to encourage discussion and suggestions for revisions. The authors are solely responsible for the contents which do not necessarily represent the opinion of the ZEW. 


\section{Non-Technical Summary}

It is a common belief that more information about climate change will lead to a better understanding of the phenomenon and to an increase of prevention measures, such as insurance for natural hazards.

To test this hypothesis, two independent surveys in Germany were conducted. The survey by the research team of KIT was based on an internet questionnaire and a sample of 510 respondents from all regions and socio-economic groups in Germany. The other survey (by researchers of ZEW) was conducted with 157 respondents which were personally present at the premises of the research institute in Mannheim.

The main objective of the analyses was to check the correlations and interactions between knowledge about climate change, scientific information about the phenomenon and the risk perception of climate-induced hazards. Furthermore the links between risk perception and prevention measures were analysed.

We found that respondents who revealed a better actual knowledge in questions about climate change perceived climate change impacts as less hazardous than those with weaker knowledge. The impact of actual knowledge is opposed to the effect of the self-declared knowledge of the respondents. Respondents who declared their own level of information about climate change as being rather high showed a higher degree of risk perception of climate change than those who ascribed themselves a lower level of information.

Overall, in both surveys independently from each other we identified certain factors determining risk perception. These are: gender (female respondents exhibited higher risk perception), experience of damages through extreme weather events (experience implies higher risk perception), and actual knowledge about climate change (better knowledge implies lower risk perception). Surprisingly, the provision of scientific information about expected climate change impacts showed no significant effect on the risk perception.

Furthermore we found a positive effect of risk perception of climate change on the willingness to insure and a significant influence of experience with damages through extreme weather events on insurance coverage.

Since information about the consequences of climate change does not lead to increased risk perception, we doubt the efficiency of large-scale public information campaigns. Given the broad coverage of the topic in mass media with partly quite drastic pictures and messages, scientifically grounded information may not enhance the awareness that climate change can impact everybody and that it is time to take action on a personal level. 


\section{Das Wichtigste in Kürze}

Es ist eine weit verbreitete Ansicht, dass mehr Informationen über den Klimawandel zu einem besseren Verständnis des Phänomens und zu einem Anstieg von Präventionsmaßnahmen, wie dem Abschluss von Versicherungen gegen Naturgefahren, führen.

Um diese Thematik zu untersuchen wurden zwei unabhängige Erhebungen durchgeführt. Die Umfrage der Forschungsgruppe des KIT basierte auf einem Online- Fragebogen mit 510 Teilnehmern aller sozio-ökonomischer Gruppierungen und aus allen Regionen Deutschlands. Die andere Umfrage (von Wissenschaftlern des ZEW) wurde mit 157 Teilnehmern durchgeführt, die in den Räumlichkeiten des Forschungsinstituts in Mannheim persönlich anwesend waren.

Das Ziel der Analysen war es, die Zusammenhänge und Wechselwirkungen zwischen dem Wissen über den Klimawandel, wissenschaftlicher Information über das Phänomen, sowie der Risikowahrnehmung bezüglich klimabedingter Gefahren zu überprüfen. Außerdem wurden die Beziehungen von Risikowahrnehmung und Präventionsmaßnahmen untersucht.

Teilnehmer, die ein besseres Wissen in Fragen des Klimawandels offenbaren, schätzen die Effekte des Klimawandels als weniger gefährlich ein als solche mit niedrigerem Wissensstand. Der Einfluss von tatsächlichem Wissen verhält sich gegenteilig zu dem des selbst deklarierten Wissens. Die Teilnehmer, die ihr eigenes Informationsniveau über den Klimawandel relativ hoch einschätzen, zeigen ein höheres Maß an Risikowahrnehmung des Klimawandels als diejenigen, die sich selbst einen niedrigeren Informationsstand zuschreiben.

Insgesamt wurden in beiden Befragungen unabhängig voneinander bestimmte Faktoren identifiziert, die die Risikowahrnehmung beeinflussen. Diese sind: das Geschlecht (weibliche Befragte zeigen eine höhere Risikowahrnehmung), Erfahrungen mit extremen Wetterereignissen (Schadenerfahrung bedeutet eine höhere Risikowahrnehmung), und das tatsächliche Wissen über den Klimawandel (besseres Wissen impliziert eine niedrigere Risikowahrnehmung). Überraschenderweise zeigt die Bereitstellung von wissenschaftlichen Informationen über die erwarteten Klimaeffekte keinen signifikanten Effekt auf die Risikowahrnehmung.

Außerdem wurden ein positiver Effekt der Risikowahrnehmung des Klimawandels auf die Bereitschaft sich zu versichern und ein signifikanter Einfluss der Erfahrung mit Schäden durch extreme Wetterereignisse auf den Versicherungsschutz gefunden.

Da Informationen über die Folgen des Klimawandels nicht zu einer steigenden Risikowahrnehmung führen, sind Zweifel über die Effizienz groß angelegter öffentlicher Informationskampagnen angebracht. Angesichts der breiten Berichterstattung über das Thema in den Massenmedien, mit teilweise recht drastischen Bildern und Nachrichten, können wissenschaftlich fundierte Informationen das Bewusstsein, dass der Klimawandel persönlich spürbare Auswirkungen haben wird und dass es Zeit zum Handeln ist, vermutlich nicht steigern. 


\title{
General knowledge about climate change, factors influencing risk perception and willingness to insure
}

\author{
Claas Menny, ${ }^{*}$ Daniel Osberghaus,${ }^{\S}$ Max Pohl ${ }^{\S}$ and Ute Werner* \\ * Karlsruhe Institute of Technology (KIT), Chair of Insurance Economics, Kronenstraße 34, 76133 Karlsruhe, \\ Germany

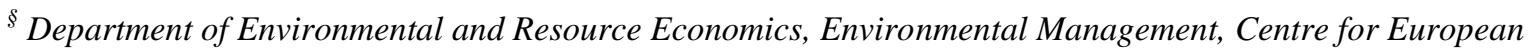 \\ Economic Research, L 7, 168161 Mannheim, Germany
}

September 2011

\begin{abstract}
In two empirical surveys in Germany the link between the information respondents have about climate change and their risk perception of the phenomenon was analysed. We found that a better understanding of the effects of climate change might lead to a decrease of the perceived hazard. In contrast, a high self-declared knowledge about climate change might correspond with higher risk perception. Further factors affecting the risk perception of climate change are gender, experience of extreme weather events and trust in external aid. Surprisingly, information campaigns based on scientific facts are not effective for increasing risk perception and willingness to insure. Higher risk perception might induce higher interest in precautionary measures like insurance.
\end{abstract}

Keywords: Climate Change, Knowledge Illusion, Insurance, Risk Perception, Information, Psychometric paradigm

JEL-Classification: Q54, Q58, D83

\footnotetext{
${ }^{1}$ Corresponding author. Email address: claas.menny@kit.edu
} 


\section{Introduction}

Climate change is the triggering mechanism for a variety of changes, but it cannot be experienced in itself. The consequences triggered by climate change happen very slowly and can only be determined through statistical analysis of temperature and precipitation data, and by continuous monitoring of their variations and the effects induced on the natural environment such as extreme weather events. These observations and analyses have to take a long view, therefore generating long-term predictions. Consequently, the derived, effects of climate change lie further in the future than the planning horizon of most individuals reaches. $^{2}$

All these factors create an image of climate change as a phenomenon in which most people can believe or not since they mainly must rely on scientific models, expert judgments, and media reports. ${ }^{3}$ Personal experiences with potential effects of climate change, e.g. longer drought periods for farmers or more frequent flooding of homes, are rare. ${ }^{4}$ Therefore it can be assumed that the majority of people rate the risk of climate change on an abstract, cognitive level which might lead to an underestimation of the hazards of climate change. ${ }^{5}$ Then again, the term 'risk' is generally understood as describing the possible downside of activities or events resulting in damages, and not so much potential positive effects. This is also the focus of our article. However, when judging risks, people might mentally counterbalance expected positive and negative effects of risks. These mental processes and the underlying differing interpretations of risk or are not covered in this article.

We concentrate on analysing the existing knowledge about climate change in two samples of the German population, the role of knowledge and scientific information for risk perception, and the resulting willingness to insure against extreme weather events. Furthermore, we analyse the influence of other factors on the perception of climate change, like sociodemographic characteristics, or the respondent's own judgement regarding their knowledge, as well as the effect of trust in external aid, science and technology, and personal experiences with extreme weather events.

It turns out that the actual knowledge about climate change corresponds to the knowledge level declared by the respondents. However, the correlation between the two is rather weak. Many people tend to overestimate the expected climate impacts in terms of key parameters, such as temperature increase or sea level rise. Regarding the personal risk perception, especially those individuals reveal a high perceived risk who (a) ascribe high damage potential to climate change, (b) expect little aid from external sources, and (c) see climate change as something new and unexplored. The factors a to $c$ in turn are related to gender,

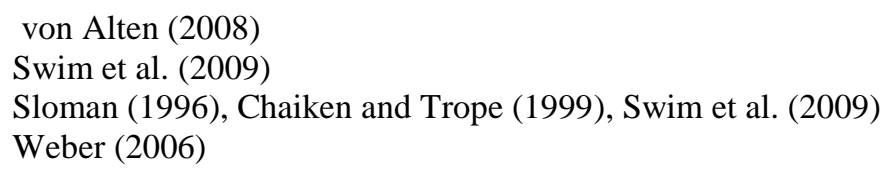


age, and experience with extreme weather events, and self-perceived and actual knowledge about climate change. Another interesting finding is that scientific information on expected climate impacts does not increase the risk perceived, possibly due to a "relaxation effect" in the group as expectations based on prior knowledge are more severe. Regarding the relation of risk perception and willingness to insure, the findings are more ambiguous. There seems to be a positive correlation between the extent of risk perceived and existing or intended insurance for extreme weather events but the effect in our samples is relatively weak.

\section{Methodology of the surveys}

The relations of/between actual and declared knowledge about climate change, perceived risk, and willingness to purchase natural hazard insurance have been analyzed by two surveys, which were developed and conducted independently by two different research teams. Even though the foci of the research groups were slightly different, it turns out that the surveys developed are complementary and compatible in the sense that both of them cover the abovementioned aspects and - if presented in connection - allow deeper insights into the complex of perceived risk and related topics.

The first study is called "study A" in this paper. It was based on an online-survey, which was conducted in Germany among 510 participants. The participants were selected according to layered quotas based on the distribution of gender, age and education level in the German population. Regarding these characteristics, the sample was representative although we made sure to include a certain minimum number of participants from 2 federal states with political conditions that might be important for the willingness to insure. Nevertheless, people from all federal states took part in this survey in March 2010.

The main part of the survey consisted of questions regarding the perception of the climate change risk, following the psychometric paradigm ${ }^{6}$ : Traditional attributes used for the rating of activities, technologies or events regarding their risk were supplemented by researchspecific characteristics. Furthermore, the respondents were questioned about their own experiences with extreme weather events, and their general knowledge about climate change issues was assessed (c.f. Appendix A1). We also asked for the sources of information used to learn about climate change, and for precautionary measures that could be taken on a personal basis. Finally, several insurance products with varying design options for weatherrelated risks were presented. Here, the respondents could indicate their willingness to buy as well as payment and prize preferences.

The second study, hereinafter called "study B", is based upon a smaller sample than study A, with 157 participants. It was conducted in February 2010. The main difference to study $A$ is that the participants of study B were divided into two treatment groups. While one group of

6 Fischhoff et al. (1978), Slovic et al. (1986) 
104 participants received an informative text about the scientific background of climate change and expected climate impacts, the control group of 53 individuals received no additional information. ${ }^{7}$ The selection of treatment groups was random. The provided informative input had been gathered from mainstream literature sources such as IPCC (2007) (as source for the scientific background and more global impacts) and national studies ${ }^{8}$, as sources for more local impacts. It was presented in the form of a two-page text in simple, easily understandable language which is attached in the Appendix B1. In order to assure that the text was really read, all participants had to be personally present in a facility of the research institute. The questionnaire about risk and insurance was distributed not before all participants have had enough time to thoroughly study the texts provided.

All participants came from the city of Mannheim in South West Germany, in the Upper Rhine Valley. The city has not been affected by major storm or flood events in recent years, but its geographical position and its building density makes it vulnerable to urban heat waves. Although all employment statuses and many professions were represented, the socio-economic structure of our sample is not assured to represent total Germany. However, these circumstances are not expected to systematically bias the results of the research questions in this paper. In particular, most statistical analyses are actually intra-sample comparisons. E.g., the absolute value of personal risk perception does not play a role, but rather its intra-sample variation and the dependence of the variation on other variables. We do not expect that these interdependencies vary considerably between different regions within Germany. Besides, all presented results of study $B$ which have a counterpart in the representative study $A$ show a convincing consistence with results from study $A$.

The questionnaire itself was divided into two parts. First, general socio-economic variables were asked, followed by a short series of knowledge questions about personal estimates of key climate change parameters. After this first part, a share of the sample was provided with the abovementioned informative text about climate change. The second part of the questionnaire elicited the personal perceived risk by a series of 17 statements about the relevance and hazard of climate change and the respective levels of agreement of respondents with these statements (c.f. Appendix B2). Preferences regarding insurance coverage were also asked in this second part of the questionnaire.

\section{Declared and actual knowledge about climate change}

Respondents of the internet-based online-study A were asked "How well are you informed about the topic of climate change?" The answer was given on a scale ranging from "I am not

\footnotetext{
7 The treatment group which received information was furthermore split into a group which received information about expected local climate impacts in South West Germany, and another group which received only information about global climate impacts. The different effects are dealt with in Osberghaus et al. (2010), but do not play a role in respect to the research questions posed in this paper. For the present analysis, both aforementioned groups are treated as one.

8 UBA (2005) and Bundesregierung (2008)
} 
at all informed" to "I am excellently informed". The result of this question is listed in Figure 1 , left panel. The majority of the respondents $(67 \%)$ declared being rather well informed (values 6 or higher). Only 22\% indicated a level of information below 5 .

But how much do the respondents really know about climate change? To find out, 8 multiple choice questions were provided. These questions and appropriate answers to them were checked beforehand by experts in the topic of climate change. Likewise, the comprehensibity of the questionnaire had been pretested several times with students and other persons. To prevent cheating, e.g. with online-searches for the correct answers, a time limit of 45 seconds per answer was set. Knowledge about climate change was measured by a score that increased with correct answers and was reduced by wrong answers. The option "I don't know" had no effect on the score. The possible range of the overall score runs from -8 to +8 . Both extremes were never reached, as can be seen in Figure 1, right panel. All questions and the multiple choice options are listed in Fehler! Verweisquelle konnte nicht gefunden werden. in the appendix A1. The relative frequency of the options chosen is listed in parentheses; correct answers are printed in bold. The majority of respondents obtained close to zero points over all.

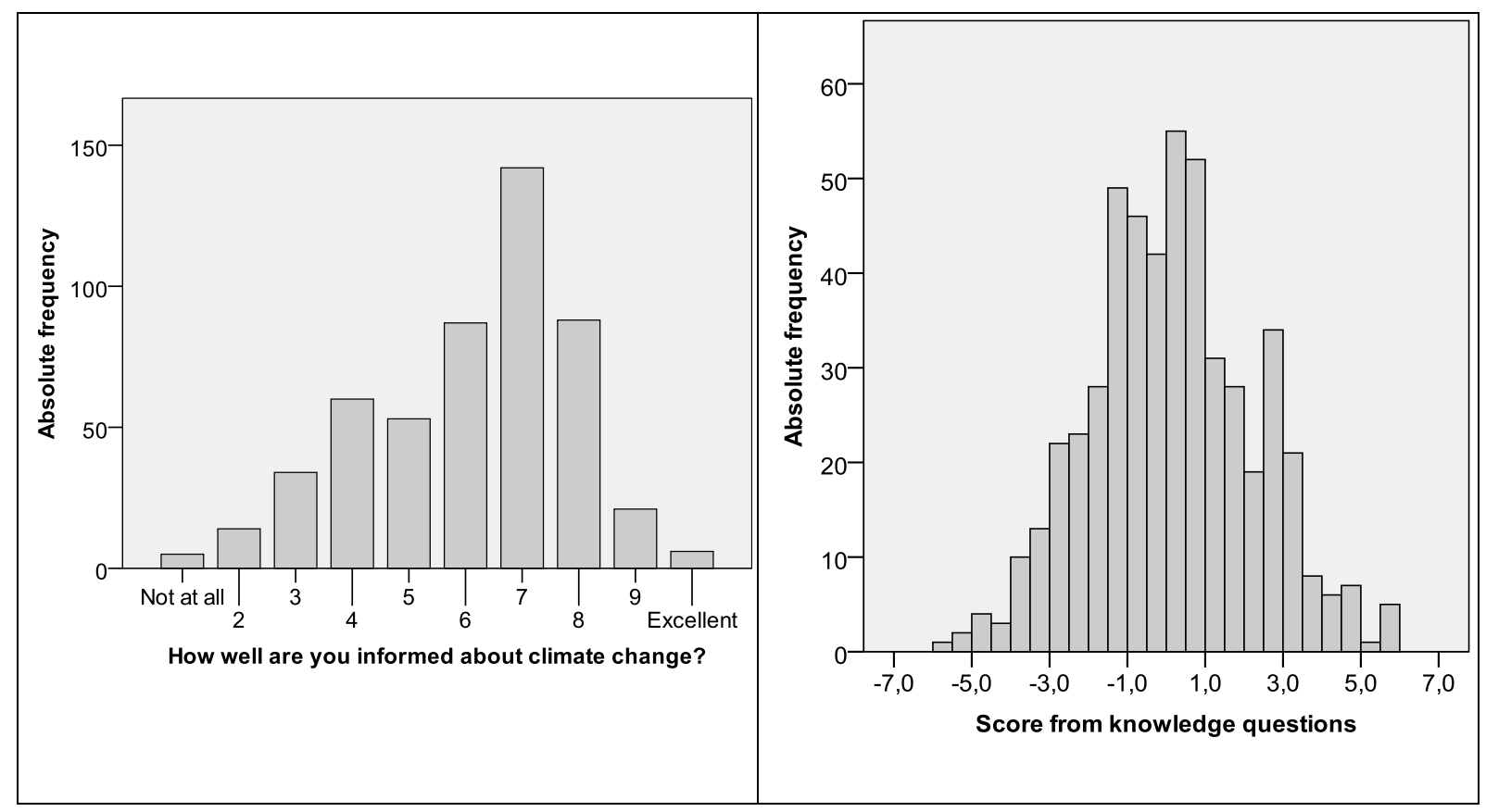

Figure 1: Study A - declared (left panel) versus actual knowledge (right panel) about climate change

The correlation between the individually declared level of information and the score obtained in the knowledge questionnaire is very weak, but significant and positive. Those who ascribed a better knowledge to themselves, actually knew slightly more facts about climate 
change (Pearsons-r $\left.=0,11^{* *}\right) .{ }^{9}$ The weakness of this correlation however fits well with findings regarding a knowledge illusion, which means that people tend to overestimate their knowledge of topics that are broadly discussed in the media. ${ }^{10}$ Therefore, the declared knowledge level of respondents is not necessarily a suitable indicator of their actual knowledge.

The pattern of relatively little knowledge about climate science is also shown by results of study B. Here participants were asked in an open-ended question about their estimation of the expected global temperature increase and the expected sea level rise within one decade. Although the "correct" answer depends on the exact decade (e.g. the correct values differ between the 1990s and the 2090s) the question was posed in this general form in order to keep it short and simple for the participants. All answers which range broadly in the uncertainty ranges of the IPCC (2007) were coded as "correct". Although these uncertainty ranges are quite high, the share of correct answers is relatively low, and almost every incorrect answer is indicating values with too high estimations. The survey also shows that people do not dare a guess (don't know answers) (see Table 1). This result indicates that most respondents are very pessimistic or quite unsure about concrete climate impacts.

\begin{tabular}{|l|l|c|l|c|}
\hline & $\begin{array}{l}\text { Underestimation of } \\
\text { impacts including } \\
\text { statements of “no im- } \\
\text { pact” and decrease }\end{array}$ & $\begin{array}{l}\text { Value given by } \\
\text { climate science } \\
\text { (IPCC 2007a) }\end{array}$ & $\begin{array}{l}\text { Overestimation } \\
\text { of impacts }\end{array}$ & $\begin{array}{l}\text { Don't } \\
\text { know- } \\
\text { answers }\end{array}$ \\
\hline $\begin{array}{l}\text { Sea level rise } \\
\text { in } 10 \text { years }\end{array}$ & $\begin{array}{l}\text { decrease, no change } \\
\text { and increase up to } 13 \\
\mathrm{~mm}\end{array}$ & $\begin{array}{l}\text { increase between } \\
13 \mathrm{~mm} \text { and } 38 \mathrm{~mm}\end{array}$ & $\begin{array}{l}\text { increase by more } \\
\text { than } 38 \mathrm{~mm}\end{array}$ & 26.4 \\
\hline $\begin{array}{l}\text { Share of re- } \\
\text { sponses (\%) }\end{array}$ & 12.9 & 18.1 & 22.6 \\
\hline $\begin{array}{l}\text { Global tem- } \\
\text { perature } \\
\text { change in } 10 \\
\text { years }\end{array}$ & $\begin{array}{l}\text { decrease, no change } \\
\text { and increase up to } \\
0.04^{\circ} \mathrm{C}\end{array}$ & $\begin{array}{l}\text { increase between } \\
0.04^{\circ} \mathrm{C} \text { and } 0.16^{\circ} \mathrm{C}\end{array}$ & $\begin{array}{l}\text { increase by more } \\
\text { than } 0.16^{\circ} \mathrm{C}\end{array}$ & \\
\hline $\begin{array}{l}\text { Share of re- } \\
\text { sponses (\%) }\end{array}$ & \multicolumn{1}{|c|}{5.8} & 1.9 & 82.6 & 9.7 \\
\hline
\end{tabular}

Table 1: Study B - Respondents' estimations of key climate impact parameters.

Although these data stem from a regional survey it is quite plausible that great parts of the German public cannot indicate the correct magnitude of meteorological changes induced by climate change and - when asked - tend to overestimate them. This phenomenon deserves definitely a deeper analysis in future, e.g. about the sources of information and the socio-

$9 * *=$ significant at the 5\%-level

10 Glenberg et al. (1982); Park (2001) 
economic background of respondent groups. Here we just want to highlight that the majority of people in Germany tend to overestimate their knowledge about climate change as well as the magnitude of climate effects in Germany.

\section{Risk perception of climate change}

In study $A$, in order to elicit the risk perception of climate change in a way comparable to other psychometric research, the respondents were asked to evaluate 8 different risks regarding their hazard potential for Germany as a whole and for them personally. The risks selected were: driving by car, smoking, floods, storms, flying by plane, crime, nuclear power and climate change. Aside from climate change, all risks mentioned had been tested before in psychometric research carried out in many countries, including Germany. The main drivers for their evaluation as more or less risky are, therefore, rather well known and include the kind of risk as technological or natural, familiar or novel, controllable or not, taken voluntarily or imposed, with consequences that are hard or easy to imagine. ${ }^{11}$ To assess the relative positioning of climate change risk, all 8 risks selected were presented to the respondents in random order and simultaneously. Therefore, the respondents rated the hazard of each activity or event with regard to all other risks. The perceived extent of hazard could be indicated by movable sliders provided by the online questionnaire. The position of the sliders was translated into values from 1 to 10, with 1 meaning "not hazardous at all" and 10 standing for "very hazardous".

One result was a ranking of the 8 risks according to the average hazard degree attributed to them for personal matters. Since the hazard degree estimates for the whole country are quite similar, it can be assumed that people are not really able to differentiate between these 2 levels of exposure. The assessments of all 510 respondents regarding their personal hazard are shown in Figure 2. Climate Change ranks at about the same level as storms, floods, and nuclear power.

11 Slovic (1992), Werner (1994) 


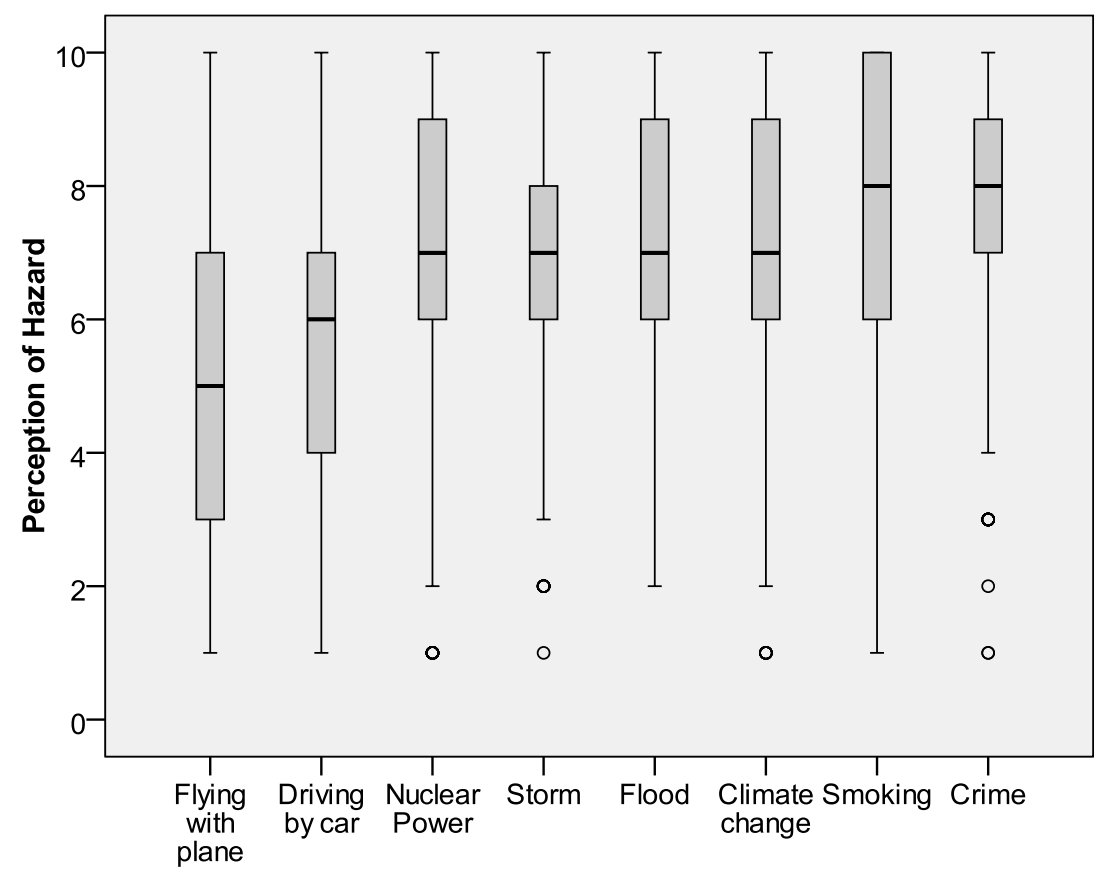

Figure 2: Study A - Perceived hazard of several risks

In study B, the perceived personal risk of respondents was elicited by a series of 17 statements about the relevance and hazardousness of climate change (c.f. Appendix B2). Based on the respective levels of agreement with the statements provided, an index for personal perceived risk (PPR) for each individual was constructed. Since the preset scale values range between 1 and 5 and are added up for each person, the individual PPR values may range between a minimum of 17 and a maximum of 85 . The distribution of the PPR index is illustrated in Figure 3.

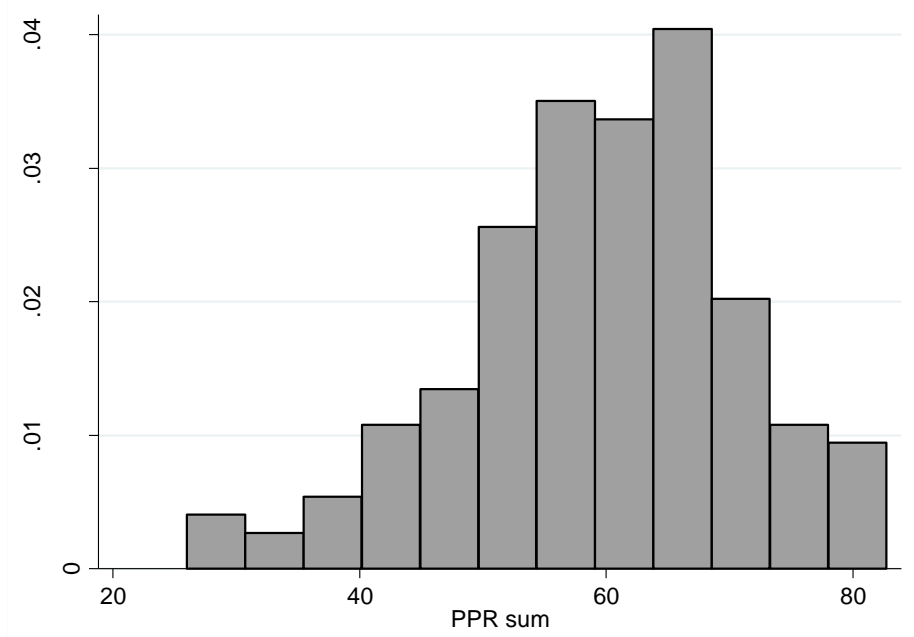

Figure 3: Study B - Histogram of PPR index of respondents 


\section{Factors influencing the risk perception of climate change}

In a further step we searched for the underlying factors that influence the perception of the hazard of climate change. Therefore, in study A we presented a series of 13 statements which were based on the psychometric paradigm ${ }^{12}$, but also on works about trust ${ }^{13}$ and perceived adaptive capacity as relevant factors for risk perception, risk attitude and risk behavior. ${ }^{14}$. The statements are listed in Table 2; they comprised risk attributes like threat, familiarity to science and to the exposed, as well as descriptions of potential risk consequences such as damages and expected benefits due to climate change, just as outlined in early psychometric research. This was completed by statements referring to individual and public means of adaptation and mitigation. Two statements dealt with trust in external help since there is evidence to suggest that this might diminish the willingness to prepare on a personal level. One statement focussed on the ease or difficulty to imagine the consequences of climate change. In order to assist the respondents in keeping this risk in mind we addressed it explicitly in each statement. From the beginning of this part of the questionnaire it was made clear, that all statements referred to the German situation.

The 13 statements were evaluated by the respondents on scales from 1 to 10 , according to their level of agreement. These statements were afterwards condensed by a principal component analysis. We found four components influencing the risk perception of climate change. Those components are shaded in Table 2 and comprise: the perceived degree of dread of climate change, the degree of trust in external aid - firefighters and other helpers as well as financial support -, the perceived potential to cope with the effects of climate change, and the degree to which the risk seems to be familiar. These four components explain $60.4 \%$ of the variance of the underlying variables, which can be taken from the rotated component matrix given in Table 2.

Slovic (1992), Brun (1992), Karger and Wiedemann (1998), Plapp (2004)

Slovic (1993); for a thorough literature review see Earle et al. (2007)

14 Grothmann and Patt (2005), Goersch (2010). 


\section{Rotated Component Matrix}

\begin{tabular}{|c|c|c|c|c|}
\hline & \multicolumn{4}{|c|}{ Component } \\
\hline & dread & $\begin{array}{l}2 \\
\text { trust in } \\
\text { external } \\
\text { aid }\end{array}$ & $\begin{array}{l}3 \\
\text { coping } \\
\text { capacity }\end{array} \mid$ & $\mid \begin{array}{l}4 \\
\text { familiarity, }\end{array}$ \\
\hline Q7 Are you afraid of the possible consequences of climate change? & ,836 & ,017 &,- 029 & 052 \\
\hline $\begin{array}{l}\text { Q8 Do you think that damages caused by extreme storms, heat, } \\
\text { heavy rain, hail or flooding will increase? }\end{array}$ & ,806 &,- 052 &,- 206 & 132 \\
\hline $\begin{array}{l}\text { Q9 Do you think it is likely that climate change will cause natural } \\
\text { disasters in Germany with many casualties? }\end{array}$ & ,838 &,- 092 & ,012 & ,061 \\
\hline $\begin{array}{l}\text { Q10 To what extent do you think climate change is explored by } \\
\text { science? }\end{array}$ & 095 &,- 031 & ,358 & 493 \\
\hline $\begin{array}{l}\text { Q11 Have you been aware of the predicted consequences of cli- } \\
\text { mate change for yourself for a long time or is this completely new } \\
\text { to you? }\end{array}$ & ,042 & ,005 &,- 252 & 811 \\
\hline $\begin{array}{l}\text { Q12 How well can you picture these consequences of climate } \\
\text { change? }\end{array}$ & ,385 & ,104 & 023 & ,677 \\
\hline $\begin{array}{l}\text { Q13 How large is the benefit you expect for yourself due to cli- } \\
\text { mate change? }\end{array}$ &,- 116 & ,139 & ,646 &,- 260 \\
\hline Q14 How large is the contribution of man to climate change? & ,563 &,- 209 &,- 032 & 190 \\
\hline $\begin{array}{l}\text { Q15 Due to technical progress, it will be possible to limit climate } \\
\text { change and to adapt to its consequences }\end{array}$ &,- 170 & ,409 &, 505 &,- 043 \\
\hline $\begin{array}{l}\text { Q16 In the case of weather-induced disasters, those impacted will } \\
\text { be assisted quickly by firefighters, civil defense, police and similar } \\
\text { institutions. }\end{array}$ &,- 118 & ,870 & ,071 & ,014 \\
\hline $\begin{array}{l}\text { Q17 In the case of weather-induced disasters, those impacted will } \\
\text { quickly obtain financial aid (private donations, government assis- } \\
\text { tance). }\end{array}$ &,- 085 & ,830 & ,198 & ,054 \\
\hline $\begin{array}{l}\text { Q18 Up to what extent do you see options for yourself to guard } \\
\text { against the dangers of climate change? }\end{array}$ & 025 & ,125 & ,785 & ,124 \\
\hline $\begin{array}{l}\text { Q19 Up to what extent do you see opportunities to make a contri- } \\
\text { bution to the mitigation of climate change? }\end{array}$ & ,489 &,- 202 & ,376 & ,213 \\
\hline \multicolumn{5}{|l|}{$\begin{array}{l}\text { Extraction method: Principal component analysis } \\
\text { Rotation method: Varimax with Kaiser-Normalisation }\end{array}$} \\
\hline Explained variance of all variables by components $1,2,3,4: R^{2}$ & \multicolumn{4}{|c|}{0,604} \\
\hline
\end{tabular}

Table 2: Study A - Statements used to assess the factors influencing risk perception of climate change

$53 \%$ of the variance of the perceived hazard of climate change can be explained with three of these components - the degree of dread, the degree of trust in external aid and the degree to which climate change is familiar to the respondents. Statistically, the factor 'coping 
capacity' shows no significant influence, whereas dread has the strongest influence on the level of perceived hazard. Respondents who fear climate change, who think it will cause disasters with many victims and an increasing amount of damages perceive this phenomenon as more hazardous than others. Respondents who have high trust that in case of disasters the firefighters and other services will help them and that they will get financial aid to cope with the aftermath perceive climate change as less hazardous. Respondents who perceive the consequences of climate change as an old, familiar problem and who claim to be able to imagine the effects of it clearly perceive this risk as more hazardous than others. The influence of the principal components on the perceived level of hazard was tested in a regression analysis. The results can be taken from Table 3.

\begin{tabular}{|l|l|}
\hline $\begin{array}{l}\mathrm{N}=510 \\
\text { Double-sided test: } \\
* * *\end{array}$ & $\begin{array}{l}\text { ANOVA } \\
\text { Dependent variable: } \\
\text { Perceived hazard of climate change }\end{array}$ \\
\hline Factor 1 - Degree of dread & $1.44^{* * *}$ \\
\hline Factor 2 - Degree of trust in external aid & $-0.167^{* * *}$ \\
\hline Factor 4 - Degree of familiarity & $0.379 * * *$ \\
\hline Constant & $7.29 * * *$ \\
\hline Goodness of fit: R2 & $\mathbf{0 . 5 3}$ \\
\hline
\end{tabular}

Table 3: Study A - Model of the aggregated principal components influencing the perceived hazard of climate change

Two of these three main components influencing the hazard ratings are themselves influenced by other variables. After dividing the sample of Study A into subgroups of respondents with common characteristics, analyses of variance were performed with the following results: People with better actual knowledge about climate change, who reached higher scores in the test questions (Appendix A1: Q21_Q28), had smaller values on the dread factor. That means: they perceived climate change and its consequences as less dreadful than people with a weaker actual knowledge about climate change. For people who already experienced damages from extreme weather events, climate change is more dreadful than for people without such experiences. Women perceived a significantly higher level of dread than men (see Table 4). 


\begin{tabular}{|c|c|c|}
\hline $\mathrm{N}=\mathbf{5 1 0}$ & & Regression coefficient \\
\hline $\begin{array}{l}\text { Factor } 1 \\
\text { dread of climate } \\
\text { change }\end{array}$ & Influenced by: & \\
\hline \multirow[t]{5}{*}{ ANOVA } & Actual knowledge (score) & $-0.043 * *$ \\
\hline & $\begin{array}{l}\text { Experience with extreme } \\
\text { weather events (yes) }\end{array}$ & $0.20 * *$ \\
\hline & Gender (male) & $-0.485^{* * *}$ \\
\hline & Constant & $0.176 * * *$ \\
\hline & Goodness of fit: $R^{2}$ & 0.072 \\
\hline $\begin{array}{l}\text { Factor } 4 \\
\text { familiarity of cli- } \\
\text { mate change }\end{array}$ & Influenced by: & \\
\hline \multirow[t]{4}{*}{ ANOVA } & Age & $0.12 * * *$ \\
\hline & Declared knowledge & $0.198 * * *$ \\
\hline & Constant & $-1.734 * * *$ \\
\hline & Goodness of fit: $\mathbf{R}^{2}$ & 0.161 \\
\hline
\end{tabular}

Table 4: Study A - Background Factors influencing the principal components dread and familiarity

The component contending the perceived familiarity of the phenomenon is influenced by the age of the respondents and by the declared knowledge about climate change. Elder respondents had higher values on this factor. For them, climate change was more familiar and they declared a better imagination of its effects than younger persons. People who claimed to be well informed about climate change had higher values on this factor as well (see Table 4). All these links and dependencies are visualized in Figure 4. 


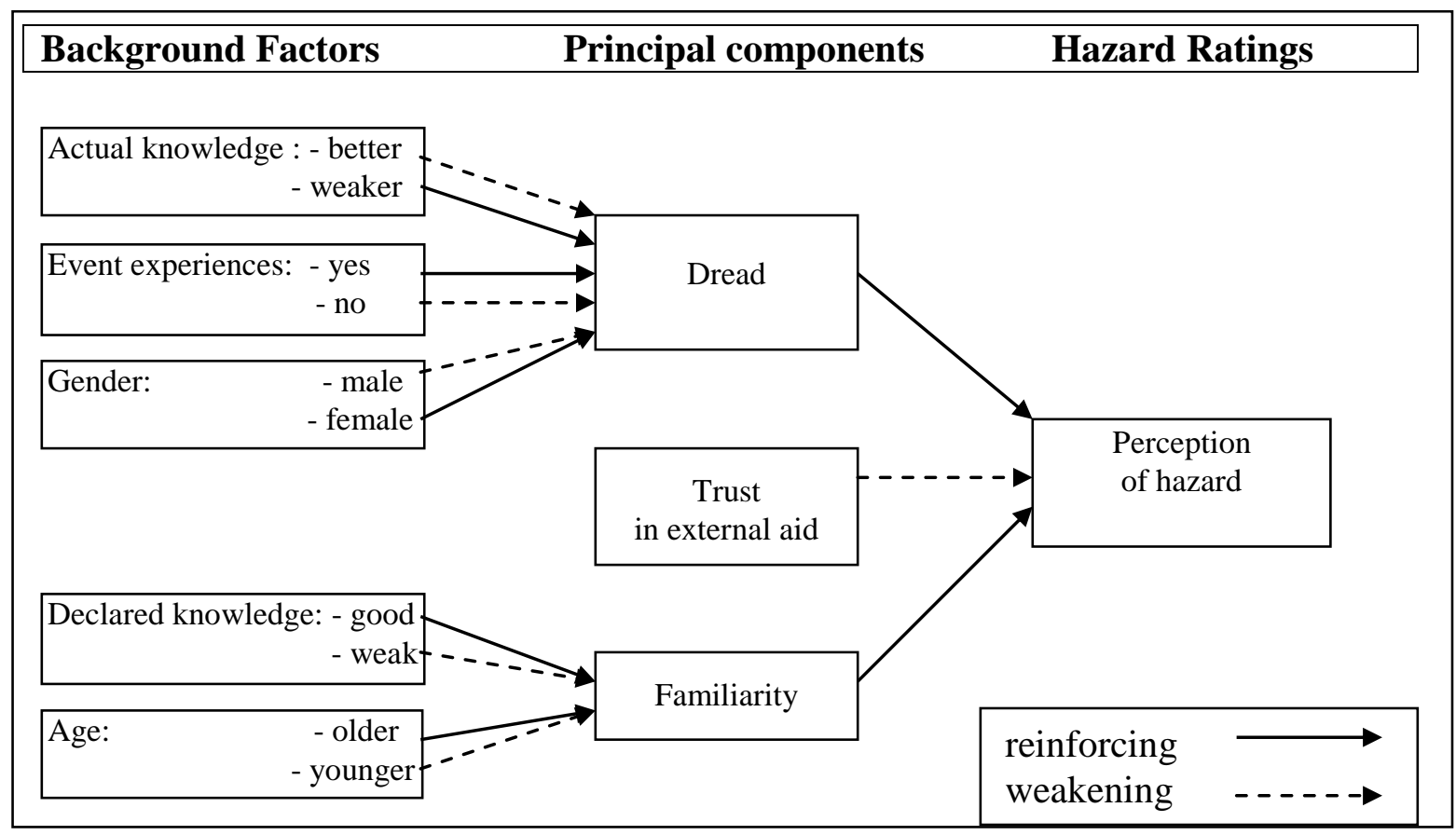

Figure 4: Study A - Reinforcing and weakening factors influencing the hazard ratings

In study B the PPR index is used as a dependent variable in a multivariate regression, in order to shed light on socio-economic variables that may have an effect on the perceived climate risk. Since the PPR index is bound to values between 17 and 85, the use of ordinary least squares is not appropriate. Instead, we transform the PPR index to values between 0 (for the theoretical minimum of 17) and 1 (for the theoretical maximum of 85 ) and use a fractional logit estimator, as proposed by Papke and Wooldridge (1996). Here the dependent variable may range continuously between 0 and 1 . The results are displayed in Table 5. 


\begin{tabular}{|l|l|}
\hline $\begin{array}{l}\text { Fractional Logit } \\
\mathrm{N}=142 \\
\text { (standard deviations in parenthesis) } \\
\text { Double-sided test: } \\
* * *=\text { significant on the 1\%-level } \\
* *=\text { significant on the 5\%-level } \\
*=\text { significant on the 10\%-level }\end{array}$ & $\begin{array}{l}\text { Dependent variable: } \\
\text { Summated score of } \\
\text { PPR items, standard- } \\
\text { ized to a value be- } \\
\text { tween 0 and 1 }\end{array}$ \\
\hline Gender: female & \\
\hline Age & $0.2775^{* *}$ \\
\hline Children & 0.0007 \\
\hline Education & 0.0482 \\
\hline Income & -0.1773 \\
\hline Home-owner & -0.0797 \\
\hline $\begin{array}{l}\text { Agreement to statement “Climate change is big- } \\
\text { gest challenge for mankind" }\end{array}$ & $0.1967^{*}$ \\
\hline Interest for climate change & $0.2510^{* *}$ \\
\hline Revealed knowledge on climate change & -0.0179 \\
\hline Feeling influenced by mass media & $-0.2191 * * *$ \\
\hline Experience of climate change impacts & $0.3521 * * *$ \\
\hline Constant & $0.3049 * * *$ \\
\hline Goodness of fit: R2 & 0.2658 \\
\hline
\end{tabular}

Table 5: Study B - Results of multivariate regression of Personal Perceived Risk.

The results reveal that some of the potentially influencing factors do not have an effect on Personal Perceived Risk in our sample. E.g., age of respondents, whether they have children or not, their level of education, income, and interest for the topic of climate change do not show a significant influence on the PPR index. Our data however reveal highly significant gender effects (positive effect for females), effects of the individual knowledge level (negative effect of high knowledge level), of experience of climate impacts (positive), and if respondents state that they feel influenced by mass media (positive). The result with regard to gender has to be interpreted with caution, though. In study A we found that women perceive all risks higher than men by about 1 point. When we ranked the perceived hazard of all risks for each respondent - from flying with an airplane to crime - climate change was on average on third place for men and for women alike.

In study B, results of the analysis of Personal Perceived Risk show a significant influence of climate knowledge. Those respondents who gave correct estimates of key climate impact parameters tend to exhibit a relatively low personal perceived risk index. The respective Pearson's correlation coefficient is -0.3078 , at a significance level of 0.001 . Also the multivariate regression results, indicated in Table 5 confirm the significant negative effect of knowledge level on PPR (significant on the 1\%-level). 


\section{External information and risk perception}

The last few years have seen an increasing coverage of the topic of climate change both in the mass media as well as in information campaigns from governments or non-governmental organisations. Most of the information aims to educate people about the increasing physical impacts which are to be expected in the coming decades and about ways to adapt to or cope with these impacts. As noted by Etkin and Ho (2007), however, there is still a large discrepancy between the level of information within the scientific community and the general public about climate change. Hence, in one way or another, information campaigns seek to increase risk awareness in order to motivate people to act against the causes and consequences of climate change.

In the previous sections, it was demonstrated, however, that our studies have generated somewhat surprising results with respect to the influence of people's level of knowledge and the subsequent level of risk perception. Recalling, study A found that individuals scoring high in knowledge questions about climate change had a relatively low feeling of dread about climate change, which correlates with low risk perception scores. Similar results were obtained in study $B$, where participants scoring high on objective knowledge questions scored comparably low on the personal risk index.

As has been stated, the topic of climate change has increasingly gained attention in the last years and numerous information campaigns, aiming to increase people's knowledge about the processes and implications of climate change, have been initiated. In the light of findings such as in study $A$ and study $B$, the question about the effectiveness of such information campaigns arises. As the provision of information seems to be one central tool to mainstream knowledge about climate change and adaptation by the general public, study B was partly devised in order to test the effect of providing information on people's personal risk perception, i.e. the effectiveness of such campaigns in instigating awareness about the potential threats of climate change.

In the study, the experimental group received two pages of specific information on the process of climate change, its expected physical impacts as well as an overview of mitigation and adaptation measures before filling out the questionnaire. The control group received no information before completing the questionnaire. The personal risk levels (PPR scores) of each participant were measured after the participants had read this information stimulus. The (translated) text of the information stimulus may be found in the Appendix B1.

To test whether the provision of information about climate change can significantly influence the personal risk perception of individuals, first the difference in mean PPR scores between the control group and the treatment group was analysed using a Wilcoxon ranked sum test. While it was found that the mean PPR scores of the treatment group were slightly higher compared to the control group, this difference was not significant at the $10 \%$ level. Hence, from this analysis it has to be concluded that providing information does in fact not 
significantly influence people's personal risk perception towards climate change. The results of this analysis can be found in Table 6.

\begin{tabular}{|l|l|l|l|c|c|}
\hline Variable & $\begin{array}{l}\text { Information } \\
\text { group }\end{array}$ & N & Mean* & $\begin{array}{c}\text { Wilcoxon } \\
\text { rank sum }\end{array}$ & p-value (rejection of H1) \\
\cline { 1 - 4 } $\begin{array}{l}\text { PPR (as summat- } \\
\text { ed score of PPR } \\
\text { items)* }\end{array}$ & $\begin{array}{l}\text { Provision of } \\
\text { information }\end{array}$ & 104 & 60.11 & 8439.5 & \multirow{2}{*}{0.4066} \\
\cline { 2 - 5 } & $\begin{array}{l}\text { No provision of } \\
\text { information }\end{array}$ & 53 & 58.14 & 3963.5 & \multirow{2}{*}{} \\
\hline
\end{tabular}

Table 6: Study B - Wilcoxon rank sum test for equality of distributions of PPR in different information treatments. H0: Distributions of PPR in both groups are equal - H1: Distributions of PPR in both groups differ from each other.

Further on, a multivariate analysis using PPR as the dependent variable was carried out following the procedure explained before. The results of this regression analysis are in line with the results from the Wilcoxon ranked sum test and also demonstrate a non-significant effect of information on individual's risk perception compared to the control group not receiving any information. Therefore, the results of study B lead to the conclusion that the provision of scientific information does not reliably influence the level of risk ratings of individuals with regard to climate change.

While the current results challenge the assumption that informing people about the potential threats of climate change will increase their personal risk perception, they also raise the question as to why such information campaigns might not be effective in causing a higher level of risk awareness. In order to shed more light on this issue specific research in this area is required. However, some general remarks shall be presented as to which processes might underlie these findings.

One reason for the lack of a significant positive effect of information on the perceived level of risk might be the relatively low severity of the communicated information. As can be seen from the answers to various knowledge items, the participants of study B tended to overestimate the expected impacts of climate change and might hence have been rather "disappointed" by the realistic, rather technical information they received. This hypothesis is given support by the significant positive effect of "feeling influenced by mass media" on the risk perception scores of our participants (see Table 5), as the images and information in the media can usually be regarded as rather "dramatic" with regular coverage of extensive flooding, dangerous heat waves or life threatening hurricanes. In contrast to the rather strong, emotional mental images about climate change that seem to have been evoked within the participants by mass media, the neutral information presented in the current study 
might thus have led people to rate the risks of climate change as rather manageable and thus score comparably low on the risk perception items.

\section{Risk perception and insurance}

Even if information campaigns about scientifically proven climate impacts may not yield the effect of higher levels of personal perceived risk, the question remains whether perceived risk with regard to climate change is relevant for private insurance demand, e.g. for natural hazard insurance. This issue may arise because perceived risk may be influenced by other measures or events, such as more populist media campaigns or - more important - personal experiences of climate-induced extreme weather events. Both effects are plausible when looking at the survey data of study B (Table 5).

Looking at the relationship of perceived risk and insurance demand, the data of both surveys yield an ambiguous message. Both surveys raise the topic of natural hazard insurance, however in different manners. In study A participants were asked whether they have actually signed an insurance police (casualty insurance, building insurance, household insurance). In study $B$, in contrast, all participants were asked about their agreement to the statement "I think it is important to purchase insurance for climate induced damages now", on a fivepoint scale from "total agreement" to "total disagreement". In other words, study A elicits the insurance coverage in a revealed preference manner, whereas study B uses stated preferences in order to measure the willingness to insure.

In study A we separated the respondents into two groups. One group was composed of individuals who had any kind of home and accident insurance and another group had none of the abovementioned insurance products. Then we conducted a logistic regression with both groups as dependent variable. It is not surprising that real estate owners had a higher probability of being insured than respondents who rent their accommodation since this has been discovered by former national and international studies, too. ${ }^{15}$ People who already experienced damages through an extreme weather event in the past also seem to have a higher probability of owning insurance policies than those without such experiences. Households with a higher number of members have a higher probability of being insured than those with fewer members. These influencing factors are also known to international disaster and insurance research. The measured risk perception of climate change showed, however, no significant correlation with the status of being insured or not. But we found a weak correlation between not believing that climate change takes place and being insured. Respondents who believe that climate change does not take place, have a higher probability of not having bought home or accident insurance than persons who believe in climate change or who are

15 see, e.g., Plapp (2004), Grothmann and Patt (2005), Kunreuther and Pauly (2005) 
undecided yet. Overall, the goodness of fit of this logistic regression is weak and the results need further research (see Table 7).

\begin{tabular}{|l|c|}
\hline $\begin{array}{l}\text { Logistic Regression } \\
\text { Double-sided test: } \\
* * * \text { significant at the 1\%-level }\end{array}$ & $\begin{array}{l}\text { Group 1: Holding one or more poli- } \\
\text { cies of home or accident insurance(n } \\
=391) \\
\text { Group 2: No such insurance ( }=119)\end{array}$ \\
\hline Real estate owner (yes) & $0.921^{* * *}$ \\
\hline Experience with extreme weather event (yes) & $0.823^{* * *}$ \\
\hline Believe that climate change does not take place & $-0.708^{*}$ \\
\hline Believe that climate change takes place & 0.221 \\
\hline Number of household members & $0.23^{*}$ \\
\hline Constant & $-0,087$ \\
\hline Pseudo- $\mathbf{R}^{\mathbf{2}}$ & $\mathbf{0 . 1 3 3}$ \\
\hline
\end{tabular}

Table 7: Study A -Who tends to buy (home) insurance?

The results of study $B$, however, suggest that perceived risk has a significant effect on private insurance demand. This could be shown by bivariate correlation analyses (Correlation coefficient of 0.30 , significant at the $1 \%$-level) and a multivariate (ordered logit) approach with the data of study $B$ (Table 8). However, the regression coefficient in Table 8 is very small. 


\begin{tabular}{|l|c|}
\hline $\begin{array}{l}\text { Ordered Logit } \\
\text { Double-sided test: } \\
* * *=\text { significant at the 1\%-level } \\
* * \text { significant at the 5\%-level }\end{array}$ & $\begin{array}{l}\text { Understanding of the necessity to } \\
\text { insure buildings against future cli- } \\
\text { mate change related damages } \\
N=138\end{array}$ \\
\hline Personal Perceived Risk & $0.0528^{* * *}$ \\
\hline Gender: female & 0.3764 \\
\hline Age & -0.0017 \\
\hline Children & -0.3880 \\
\hline Education & $-0.8521 * *$ \\
\hline Income & 0.3263 \\
\hline Home-owner & 0.3082 \\
\hline $\begin{array}{l}\text { Agreement to statement “Climate change is biggest } \\
\text { challenge for mankind” }\end{array}$ & -0.1265 \\
\hline Interest for climate change & -0.5084 \\
\hline Revealed knowledge on climate change & $-0.5038 * *$ \\
\hline Feeling influenced by mass media & 0.1074 \\
\hline Stated experience of climate change impacts & 0.0849 \\
\hline Stated Expectation of Public Relief in case of need & 0.2726 \\
\hline Pseudo-R & $\mathbf{0 . 0 7 9 1}$ \\
\hline
\end{tabular}

Table 8: Study B - Factors influencing the understanding of the need to insure

These results show that the theoretical (positive) relation of personal perceived risk and motivation to protect, e.g. by insurance, exists in our samples. However, other factors may play important roles, too. By the existing data we cannot exclude that variables not measured in our surveys, e.g. personal risk attitude, and prior experience with insurance policies, have a much greater effect on insurance demand than personal perceived risk with regard to climate change. This topic definitely deserves more and deeper research.

\section{Conclusion}

One main goal of the analysis was to check the correlations and interactions between knowledge about climate change and the risk perception of climate change. In study A, we found in fact no significant correlation between the score from the knowledge questions and the hazard perception, but we found a correlation with the dread-factor as the main compo- 
nent influencing risk perception of climate change. Respondents who revealed a better knowledge in the questions about climate change perceived the climate change impacts as less dreadful than those with weaker knowledge. This was confirmed in study $B$, where respondents who revealed a better knowledge had perceived a lower degree of risk than those with less accurate knowledge about the effects of climate change. Respondents in study $A$ who declared their own level of information about climate change as being rather high, appraised climate change as a known phenomenon and ascribed to themselves a good ability to imagine its effects. This, however, may lead to a higher degree of risk perception of climate change.

Strong trust in the function of external aid services in case of extreme weather events - firefighters and other helpers as well as financial support - leads to decreased risk perception of climate change.

Overall, both surveys independently from each other identified certain factors determining risk perception. These are gender, experience of extreme weather events, and actual knowledge about Climate Change.

The finding of study B regarding the non-effectiveness of climate impact information should evoke concern about the cost and benefit of large-scale campaigns to inform the public about expected climatic effects. Given the broad coverage of the topic in mass media with partly quite drastic pictures and messages, scientifically grounded information may not enhance the awareness that climate change can impact everybody and that it is time to take action on a personal level, too.

A significant effect of risk perception on the willingness to insure was exposed in study $B$, but not in study A. However, in study A we found a significant influence of experience with damages through extreme weather events on insurance coverage.

Regarding the expected effects of climate change we - as a society - should be interested in precautionary measures of all kinds and on all institutional levels. Instead of multiple large scale information campaigns, other strategies, e.g. site-specific risk evaluation and communication about concrete protection measures may be more effective. Additionally, focussing on concrete, tangible effects of climate change such as "inundation" or "storm hazard" could help to ground the elusive concept of climate change. This may be a topic for further research. 


\section{References}

Brun, W. (1992) 'Cognitive Components in Risk Perception. Natural Versus Manmade Risks', Journal of Behavioral Decision Making 5(2): 117-132.

Bundesregierung (2008) Deutsche Anpassungsstrategie an den Klimawandel - German Strategy for Adaptation to Climate Change, http://www.bmu.de/klimaschutz/downloads/doc/42783.php.

Chaiken, S. and Trope, Y. (1999) Dual-Process Theories in Social Psychology, New York: Guilford Press.

Earle, T.C., Siegrist, M. and Gutscher, H. (2007) Trust, Risk Perception and the TCC Model of Cooperation. In Trust in Cooperative Risk Management. Uncertainty and Cooperation in the Public Mind, ed. by Siegrist, M., Earle, T.C. and Gutscher, H., London: Earthscan Reader: 1-50. Etkin, D. and Ho, E. (2007) 'Climate Change: Perceptions and Discourses of Risk', Journal of Risk Research 10(5): 623-641.

Fischhoff, B., Slovic, P., Lichtenstein, S., Read, S. and Combs, B. (1978) 'How Safe is Safe Enough? A Psychometric Study of Attitudes Towards Technological Risks and Benefits', Policy Sciences, 9(2): 127-152.

Goersch, H. (2010) Empirische Untersuchung von Möglichkeiten der Förderung der Persönlichen Notfallvorsorge in Deutschland. Dissertation, University of Karlsruhe / KIT, digbib.ubka.uni-karlsruhe.de/volltexte/1000016069.

Glenberg, A. M., Wilkinson, A. C. and Epstein, W. (1982) 'The Illusion of Knowing. Failure in the Self-Assessment of Comprehension', Memory \& Cognition 10(6): 597-602.

Grothmann, T. and Patt, A. (2005) 'Adaptive Capacity and Human Cognition. The Process of Individual Adaptation to Climate Change', Global Environmental Change 15(3): 199-213.

IPCC (2007) Climate Change - Fourth Assessment Report of the Intergovernmental Panel on Climate Change, Cambridge and New York: Cambridge University Press.

Karger, C. R. and Wiedemann, P. M. (1998) 'Kognitive und affektive Komponenten der Bewertung von Umweltrisiken', Zeitschrift für experimentelle Psychologie 4(45): 334-344.

Kunreuther, H. and Pauly, M. (2005) 'Insurance Decision-Making and Market Behavior', Foundations and Trends in Microeconomics 1(2): 63-127.

Osberghaus, D., Finkel, E. and Pohl, M. (2010) 'Individual Adaptation to Climate Change: the Role of Information and Perceived Risk', Discussion Paper No. 10-061, Centre for European Economic Research (ZEW), Mannheim. 
Papke, L.E. and Wooldridge, J.M. (1996) 'Econometric Methods for Fractional Response Variables with an Application to 401(k) Plan Participation Rates', Journal of Applied Econometrics 11: 619-632.

Park, C. Y. (2001) 'News Media Exposure and Self-Perceived Knowledge. The Illusion of Knowing', International Journal Of Public Opinion Research. 13(4): 19-425.

Plapp, T. (2004) Wahrnehmung von Risiken aus Naturkatastrophen. Eine empirische Untersuchung in sechs gefährdeten Gebieten Süd- und Westdeutschlands, Karlsruhe: Verlag Versicherungswirtschaft.

Schuchardt, B., Wittig, S., Mahrenholz, P., Kartschall, K., Mäder, C., Hasse, C. and Daschkeit, A. (2008) Germany in the Midst of Climate Change: Adaptation is Necessary, Umweltbundesamt, KomPass (Competence Centre on Climate Impacts and Adaptation), 4-13.

Sloman, S. A. (1996) 'The Empirical Case for Two Systems of Reasoning', Psychological Bulle$\operatorname{tin} 119(1): 3-22$.

Slovic, P., Fischhoff, B. and Lichtenstein, S. (1986) 'The Psychometric Study of Risk Perception'. In Covello, V.T., Menkes, J. and Mumpower, J. (Eds.), Risk Evaluation and Management. New York, Plenum: 3-24.

Slovic, P. (1993) 'Perceived Risk, Trust, and Democracy', Risk Anal. 13: 675-682.

Slovic, P. (1992) 'Perceptions of Risk: Reflections on the Psychometric Paradigm', in Krimsky, S. and Golding, D. (eds.) Social theories of risk: Praeger, 117-152.

Starr, C. (1969) 'Social Benefit Versus Technological Risk' Science 165(3899): 1232-1238.

Swim, J., Clayton, S., Doherty, T., Gifford, R., Howard, G., Reser, J. et al. (2009) Psychology and Global Climate Change. Addressing a Multi-Faceted Phenomenon and Set of Challenges. American Psychological Association, Washington, DC.

UBA (2005) Klimawandel in Deutschland - Vulnerabilität und Anpassungsstrategien klimasensitiver Systeme, Forschungsbericht 20141 253, Umweltbundesamt, Federal Environmental Agency, Dessau, Germany.

von Alten, G. (2008) Das Risikoverhalten von Landwirten. Eine Studie am Beispiel der Erntemehrgefahrenversicherung. Dissertation. University of Göttingen, Germany.

Weber, E. (2006) 'Experience-Based and Description-Based Perceptions of Long Term Risk. Why Global Warming does not Scare Us (yet)', Climatic Change 77(1): 103-120.

Werner, U. (1994) Aspects of Multicultural Marketing of Insurance Companies, The Geneva Papers on Risk and Insurance 19: 196-214. 


\section{Appendix}

\section{B1: Informative text about climate change and expected impacts in study B}

Note: In the survey, either the chapter on global impacts or on regional impacts has been provided to the participants. The other chapters (e.g. causes of climate change) were distributed to all treated participants.

\section{Global Climate Change [both subgroups]}

Current available evidence indicates that there have already been significant changes in climate and climate-related effects throughout various regions of the world. According to scientific consensus, climate change is "already happening, unequivocal and this change can now be firmly attributed to human activity." Over the past 100 years, the average global temperature has risen $0.74 \mathrm{C}$, with most of the warming occurring in the past 50 years. If greenhouse gas emissions continue to increase at their present rate, average global temperature could rise to about $3 \mathrm{C}$ by the end of this century. Further warming may induce many changes in the global climate system during the $21^{\text {st }}$ century that would very likely surpass those that have occurred in the previous century.

\section{A Definition of Climate Change [both subgroups]}

A change in the state of the climate that can be identified (e.g. using statistical tests) by changes in the mean and/or the variability of its properties, and that persists for an extended period, typically decades or longer. It refers to any change in climate over time, whether due to natural variability or as a result of human activity.

\section{Causes of Climate Change [both subgroups]}

Climate scientists concur that principal reason for the increase in temperature and related weather and climate events is the result of a century and a half of industrialization. Human activities such as the burning of oil, gasoline and coal, the increase in deforestation and certain farming methods have increased the emissions of so-called "greenhouse gases" (GHGs) in the atmosphere. These gases, which include carbon dioxide, methane and nitrous oxide among others, have amassed in the atmosphere to a quantity that is interfering with the balance of the world's climate system.

GHGs are naturally occurring gases which affect the absorption, scattering and emission of radiation within the atmosphere and at the Earth's surface. These gases are vital for mediating the temperature of the planet and thus are essential for life on earth. However, global atmospheric concentrations of carbon of GHGs have increased markedly since 1750 and now far exceed pre-industrial values. 
The largest growth in GHG emissions between 1970 and 2004 has come from energy supply, transport and industry. Annual emissions of carbon dioxide, the most important anthropogenic GHG, have grown between 1970 and 2004 by about 80\%, from 21 to 38 gigatonnes (Gt), and represented 77\% of total anthropogenic GHG emissions in 2004.

The clear increase in the atmospheric concentrations of these gases is augmenting global temperatures to artificially high levels and, as a result, altering the climate. The 1990s have been recorded as the warmest decade of the last millennium. Moreover it is deemed virtually certain that this trend of warmer and more frequent hot days over most land regions will continue within the next century.

\section{Predicted Global Impacts [subgroup 'global impacts']}

Current projections state that trends in extreme weather events, along with other risks such as glacier melting and sea level-rise, are already occurring at a lower level of temperature rise than expected and are likely to increase within the next century. Between 1990 and 2008 almost 600,000 people died directly from more than 11,000 extreme weather events, and losses of 1.7 trillion USD occurred (in 2008 values). Bangladesh, Myanmar and Honduras have been identified to be the most affected. They are followed by Vietnam, Nicaragua, Haiti and India. Further examples global impacts by sector are listed below.

\section{Agricultural Effects:}

- Increased temperature is expected to enhance crop yields in temperate areas, but decrease crop yields in tropical areas, increasing the risk of hunger.

- Changes in agricultural and forestry management at Northern Hemisphere latitudes are possible, such as earlier spring planting of crops and alterations in disturbances to forests due to fires and pests.

- Increases in the frequency of droughts and floods are projected to affect local and crop production negatively especially in subsistence sectors at low latitudes.

- Agricultural production, including access to food, in many African and Latin American countries is projected to be severely compromised. This would further adversely affect food security and exacerbate malnutrition.

- There may be an increased yield of rain-fed agriculture by $5-20 \%$ in North America, but with variability among regions.

\section{Health Effects:}

- Predicted threats on some aspects of human health include excess heatrelated mortality in Europe and North America, changes in Infectious Disease 
vectors in parts of Europe and an earlier onset and increases in seasonal production of allergic pollen.

- The changes will be mostly felt by those least able to adapt, such as the poor, the very young and the elderly.

- There are projected increases in malnutrition; increased deaths, diseases and injury due to extreme weather events; increased burden of diarrhoeal diseases; increased frequency of cardio-respiratory diseases due to higher concentrations of ground-level ozone in urban areas related to climate change; and the altered spatial distribution of some infectious diseases in many world regions.

\section{Biodiversity Effects:}

- A likely increased risk of extinction among $20-30 \%$ of plant and animal species is expected if global temperature increase exceeds $1.5-2.5 \mathrm{C}$.

- There is high confidence in changes in terrestrial biological systems i.e. earlier timing of spring events such as leaf unfolding, bird migration and egg-laying, as well as pole-ward and upward movement of plant and animal species.

- Enlargement of glacial lakes, increasing ground instability in permafrost regions and rock avalanches in mountain regions may cause changes in some Arctic and Antarctic ecosystems, including those in sea-ice biomes, and predators at high levels of the food web.

- Gradual replacement of tropical forest by savanna in eastern Amazonia is expected to occur, as well as a risk of significant biodiversity loss through species extinction in many areas of tropical Latin America.

- There will be a likely reduction in the thickness and extent of glaciers, ice sheets and sea ice, with changes in related ecosystems and detrimental effects on many organisms.

- Specific ecosystems and habitats are projected to be vulnerable as climatic barriers to species invasions are lowered in Polar Regions.

\section{Coastal Effects and Water Availability:}

- Coasts are projected to be exposed to increasing risks, including coastal erosion and sea-level rise. Densely-populated and low-lying areas, where adaptive capacity is relatively low, are especially at risk.

- Sea-level rise in small island developing states may exacerbate inundation, storm surge, erosion and other coastal hazards, thus threatening vital infrastructure that supports the socio-economic well-being of island communities. 
- Large populations in Asian Mega deltas (i.e. Genges-Brahmaputra and the Zhujiang) may have a high exposure to seal-level rise, storm surge and river flooding.

- Increased stress on coastal communities and habitats in North America is expected as a result of climate change impacts.

- In Europe there will be an increased risk of inland flash floods, more frequent coastal flooding and increased erosion, as well as glacier retreat in mountainous areas.

- By mid-century, water availability is predicted to increase by $10-40 \%$ at high latitudes and in some wet tropical areas, and decrease by $10-30 \%$ over some dry regions at mid-latitudes and in the dry tropics, some of which are presently water stressed areas.

- Water resources may be compromised in small island communities e.g. the Caribbean and the Pacific, to the point where they become insufficient to meet demand during low-rainfall periods.

- Up to 250 million people in Africa at increased risk of water stress by 2020 due to water shortages.

- Freshwater availability in Central, South, East and South-East Asia is predicted to decrease by the 2050s

- Warming in western North American mountains is projected to cause decreased snowpack, more winter flooding and reduced summer flows.

\section{Economic effects:}

- Higher summer temperatures will lead to increased energy demand for space cooling in many regions.

- Climate change may lead to increased energy related costs, coastal and storm damage related costs, health-related costs, etc. Economic impacts will be unevenly distributed across regions and within the economy and society.

- Impacts will place immense strains on public sector budgets and some secondary effects of climate impacts can include higher prices, reduced income and job losses.

- Climate change has the potential to push developing countries back into the poverty trap and to undo many achievements that have been made to date with regard to the Millennium Development Goals (MDGs) 
- Reduced snow cover and winter tourism is expected in some European countries.

- Southern Europe will face higher temperatures and drought, reduced water availability, hydropower potential, summer tourism and crop productivity.

\section{Predicted Impacts within Germany [subgroup ‘local impacts’]}

Current research shows that the annual mean temperature in Germany over the past 100 years rose by about $0.8 \mathrm{C}$ and in the past decades this warming trend has increased to nearly double that rate at a pace of $0.15 \mathrm{C}$ per decade. By 2100 temperatures in Germany will be likely to increase with regional and seasonal differences by 1.5 to $3.7 \mathrm{C}$. In the past 100 years precipitation has increased significantly, primarily in western Germany, with the greatest increase taking place in winter. Climate change is also manifesting itself in the unusual intensity of extreme weather events such as heat periods and heavy precipitation. They are longer in duration, more frequent or more intense. There will be fewer frost days, more hot days and more tropical nights, and the number and duration of heat waves will increase. Studies show that southwest Germany (Upper Rhine Graben), the central sections of eastern Germany and the Alps have the highest vulnerability to climate changes.

\section{Health Effects:}

- Illnesses and injuries caused by heat waves, storms, floods avalanches or landslides expected to increase

- Altered areas of spread of vector-borne diseases

- Great heat intensities in cities may lead to more cardiovascular problems and even deaths.

- For the Upper Rhine Graben climate change will become manifest in particular by a substantial increase in hot days and nights as well as in the number and duration of hot seasons. This increase will be a challenge for the health care sector in particular.

\section{Agriculture and Forestry:}

- Impairment of crop yields particularly in regions that will be more arid in the future

- Increase in soil erosion, mounting risk of impeded drainage, flooding or drought stress

- Increased vulnerability of forests unsuitable for their location as well as greater risks of forest fires

- Increasing pressure due to pests and extreme weather conditions. 
- Above average rise in winter precipitation for the North Sea coast and the northwest German lowlands and a particularly sharp decrease in summer precipitation for the Baltic Sea coast and the north eastern lowlands. This may lead to problems in agriculture or water management in the northeast regions, which have already been affected by drought.

\section{Water Management:}

- Summer precipitation will decline by 30 percent on average. However, the frequency of heavy precipitation will increase, with greater risk of floods in winter and spring

- More frequent low water in summer and altered groundwater tables with possible consequences for drinking water supply

- The highest increase in average winter precipitation in all of Germany is expected in the low mountain range region on both sides of the Rhine. Summer precipitation will decline to a relatively minor extent. Consequences can be expected for agriculture and forestry as well as for flood protection.

$\underline{\text { Nature conservation and biodiversity: }}$

- Threat to species diversity, especially in wetlands and mountainous regions, with consequences for nature and conservation goals.

\section{Tourism:}

- We must expect a shrinkage in glaciers and snow cover in the Alps

- Reduced snow-reliability in mountainous regions for winter tourism, though improved prospects of economic success for tourist destinations on the coasts

- Possible negative consequences for tourists because of increased occurrence of jellyfish and toxic algae on the coasts.

\section{Flood and Coastal Protection:}

- More frequent and intensive flood events place demands on flood and coastal protection facilities

- The sea level could rise significantly by $30 \mathrm{~cm}$ on average, with a considerably higher rise in sea level expected for part of the coasts in Germany due to land subsidence and enlargement of the tidal range.

\section{Economic effects:}

- Past extreme weather effects have amounted to very high damage costs in Germany. The Elbe flood in 2002 caused total economic damage of $€ 9.4$ billion 
- The hurricanes "Lothar" and "Martin" in 1999 were responsible for damage amounting to over $€ 14$ billion.

- In addition, as a consequence of the hot summer in 2003 , statisticians counted over 7,000 deaths more than in normal summers in Germany.

\section{Mitigation and Adaptation to Climate Change [both subgroups]}

Societies can respond to climate change through two processes: mitigation and adaptation. The standard definitions of mitigation and adaptation agreed upon by scientists are the following:

Mitigation: Technological change and substitution that reduce resource inputs and emissions per unit of output. Although several social, economic and technological policies would produce an emission reduction, with respect to Climate Change, mitigation means implementing policies to reduce greenhouse gas emissions and enhance sinks.

Adaptation: Initiatives and measures to reduce the vulnerability of natural and human systems against actual or expected climate change effects. Various types of adaptation exist, e.g. anticipatory and reactive, private and public, and autonomous and planned. Examples are raising river or coastal dikes, the substitution of more temperature-shock resistant plants for sensitive ones, etc.

\section{B2: Questions for eliciting Personal Risk Perception in study B}

How concerned are you about the issue of climate change?

\begin{tabular}{|c|c|c|c|c|c|}
\hline $\begin{array}{c}\text { Not at all con- } \\
\text { cerned }\end{array}$ & $\begin{array}{c}\text { Rather not } \\
\text { concerned }\end{array}$ & Neutral & $\begin{array}{c}\text { Rather con- } \\
\text { cerned }\end{array}$ & $\begin{array}{c}\text { Strongly con- } \\
\text { cerned }\end{array}$ & Don't know \\
\hline 1 & 2 & 3 & 4 & 5 & $\cdot$ \\
\hline
\end{tabular}


To what degree do you feel/think that climate change poses a serious hazard for the group of people mentioned below?

\begin{tabular}{|c|c|c|c|c|c|c|}
\hline & $\begin{array}{c}\text { No serious } \\
\text { danger at } \\
\text { all }\end{array}$ & $\begin{array}{c}\text { Rather } \\
\text { no serious } \\
\text { danger }\end{array}$ & Neutral & $\begin{array}{l}\text { Rather } \\
\text { serious } \\
\text { danger }\end{array}$ & $\begin{array}{l}\text { Very seri- } \\
\text { ous danger }\end{array}$ & $\begin{array}{l}\text { Don't } \\
\text { know }\end{array}$ \\
\hline Myself & 1 & 2 & 3 & 4 & 5 & . \\
\hline My children & 1 & 2 & 3 & 4 & 5 & . \\
\hline $\begin{array}{l}\text { Future Generations in } \\
\text { general }\end{array}$ & 1 & 2 & 3 & 4 & 5 & . \\
\hline $\begin{array}{l}\text { The region around } \\
\text { Mannheim }\end{array}$ & 1 & 2 & 3 & 4 & 5 & . \\
\hline The people in Germany & 1 & 2 & 3 & 4 & 5 & . \\
\hline
\end{tabular}


How likely do you feel/think it is that the following expected effects of climate change will have a personal impact on you?

\begin{tabular}{|l|c|c|c|c|c|c|}
\hline & $\begin{array}{c}\text { Very un- } \\
\text { likely }\end{array}$ & $\begin{array}{c}\text { Rather } \\
\text { unlikely }\end{array}$ & Neutral & $\begin{array}{c}\text { Rather like- } \\
\text { ly }\end{array}$ & Very likely & $\begin{array}{c}\text { Don't } \\
\text { know }\end{array}$ \\
\hline $\begin{array}{l}\text { Increased flooding } \\
\text { due to heavy rain- } \\
\text { fall }\end{array}$ & 1 & 2 & 3 & 4 & 5 & $\cdot$ \\
\hline Increasing droughts & 1 & 2 & 3 & 4 & 5 & $\cdot$ \\
\hline $\begin{array}{l}\text { Increasing illnesses } \\
\text { Itrong heatwaves }\end{array}$ & 1 & 2 & 3 & 4 & 5 &. \\
\hline $\begin{array}{l}\text { Increasing number } \\
\text { of natural disasters } \\
\text { generally }\end{array}$ & 1 & 2 & 3 & 4 & 5 &. \\
\hline $\begin{array}{l}\text { Climate-related } \\
\text { refugees from for- } \\
\text { eign countries } \\
\text { tax/ climate- in- } \\
\text { surance }\end{array}$ & 1 & 2 & 3 & 4 & 5 & \\
\hline $\begin{array}{l}\text { Additional costs } \\
\text { due to climate- }\end{array}$ & 1 & 2 & 3 & 4 & 5 & \\
\hline
\end{tabular}

When do you expect the effects of climate change to take place?

\begin{tabular}{|c|c|c|c|c|c|}
\hline Never & $\begin{array}{c}\text { In more } \\
\text { than } 50 \\
\text { years }\end{array}$ & $\begin{array}{c}\text { Whithin the next } \\
50 \text { years }\end{array}$ & $\begin{array}{c}\text { Whithin the next } \\
10 \text { years }\end{array}$ & $\begin{array}{c}\text { Already tak- } \\
\text { ing place }\end{array}$ & Don't know \\
\hline 1 & 2 & 3 & 4 & 5 & $\cdot$ \\
\hline
\end{tabular}


How often do you think about the negative effects of climate change on your personal life?

\begin{tabular}{|c|c|c|c|c|c|}
\hline Never & $\begin{array}{c}\text { Rather sel- } \\
\text { dom }\end{array}$ & Neutral & Rather often & Always & Don't know \\
\hline 1 & 2 & 3 & 4 & 5 & $\cdot$ \\
\hline
\end{tabular}

How strongly do you agree with the following statement? "I will experience the impacts of climate change in my lifetime."

\begin{tabular}{|c|c|c|c|c|c|}
\hline $\begin{array}{c}\text { Strongly disa- } \\
\text { gree }\end{array}$ & $\begin{array}{c}\text { Rather disa- } \\
\text { gree }\end{array}$ & Neutral & Rather agree & $\begin{array}{c}\text { Strongly } \\
\text { agree }\end{array}$ & Don't know \\
\hline 1 & 2 & 3 & 4 & 5 & \\
\hline
\end{tabular}

Do you think that you personally will be noticeably affected by climate change consequences?

\begin{tabular}{|c|c|c|}
\hline No & Yes & $\begin{array}{c}\text { Don't } \\
\text { know }\end{array}$ \\
\hline 0 & 5 & $\cdot$ \\
\hline
\end{tabular}


A1: Knowledge questions in study A

\begin{tabular}{|c|c|c|}
\hline & Question & Answers[ correct answers are printed in bold \\
\hline Q21 & $\begin{array}{l}\text { Which animals contribute sig- } \\
\text { nificantly to emissions of } \\
\text { greenhouse gases into the at- } \\
\text { mosphere? }\end{array}$ & $\begin{array}{l}\text { Cattle }(68.4 \%) \text {, dogs }(4.3 \%) \text {, reptiles }(2.5 \%) \text {, polar } \\
\text { bears }(3.9 \%) \text {, none }(19.4 \%) \text {, don't know }(9.2 \%)\end{array}$ \\
\hline Q22 & $\begin{array}{l}\text { Which of the following factors } \\
\text { are likely to contribute to cli- } \\
\text { mate change? }\end{array}$ & $\begin{array}{l}\mathrm{Co}_{2} \text {-emissions }(82.9 \%) \text {, methane - emissions } \\
(38.4 \%) \text {, deforestation }(64.1 \%) \text {, } \\
\text { hydrogen sulfide emissions (19\%), the ozone hole } \\
(61.2 \%) \text {, none of those }(1.6 \%) \text {, don't know }(2.5 \%)\end{array}$ \\
\hline Q23 & $\begin{array}{l}\text { What is the International Panel } \\
\text { on Climate Change (IPCC)? }\end{array}$ & $\begin{array}{l}\text { An international body with the task to present the } \\
\text { state of research on climate change, the associated } \\
\text { risks and mitigation and adaptation strategies } \\
\text { (27.3\%) } \\
\text { A UN forum for the coordination of environmental } \\
\text { and climate policy of all participating nations } \\
\text { (14.7\%) } \\
\text { A supranational body to discuss and coordinate the } \\
\text { implementation of the decisions of the Kyoto Pro- } \\
\text { tocol (11.4\%) } \\
\text { A non-profit organization that provides a platform } \\
\text { for trade of emission-certificates ( } 2.4 \% \text { ). } \\
\text { don't know (44.3\%) }\end{array}$ \\
\hline Q24 & $\begin{array}{l}\text { By how much did the global } \\
\text { temperature rise from the be- } \\
\text { ginning of the recordings in } \\
1860 \text { until today? }\end{array}$ & 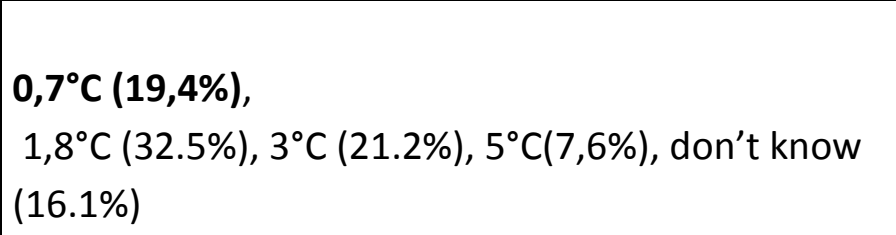 \\
\hline Q25 & $\begin{array}{l}\text { Politicians of many countries } \\
\text { are trying to make arrange- } \\
\text { ments to limit climate change. } \\
\text { Which global climate target do } \\
\text { they intend to achieve? (In } \\
\text { comparison to preindustrial } \\
\text { times) }\end{array}$ & $\begin{array}{l}\text { max. } 2^{\circ} \mathrm{C} \text { warming (31.2\%) } \\
\text { no warming (6,9\%) } \\
\text { max. } 1^{\circ} \mathrm{C} \text { warming }(17.1 \%) \text {, max. } 3^{\circ} \mathrm{C} \text { warming } \\
(9.8 \%) \text {, max. } 4^{\circ} \mathrm{C} \text { warming }(3.1 \%) \text {, don't know (32\%) }\end{array}$ \\
\hline Q26 & $\begin{array}{l}\text { Which average global sea level } \\
\text { rise is predicted by most cli- }\end{array}$ & $\begin{array}{l}\text { Less than } \mathbf{2} \text { meters }(\mathbf{4 0 , 2} \%) \text {, } \\
\text { none }(2 \%) \text {, less than } 5 \text { meters }(29,2 \%) \text {, less than } 7\end{array}$ \\
\hline
\end{tabular}




\begin{tabular}{|l|l|l|}
\hline Q27 & mate scientists until 2100? & meters (9,6\%), don't know (19\%) \\
\hline $\begin{array}{l}\text { Whate change in Germany? } \\
\text { Q28 }\end{array}$ & $\begin{array}{l}\text { Which sector is the main source } \mathrm{CO}_{2} \text { in Germany } \\
\text { (27,1\%), advantages in winegrowing (9\%), spread- } \\
\text { ing of new parasites (51,8\%) } \\
\text { less precipitation in winter (21,4\%), colder sum- } \\
\text { mers (28,8\%), desertification (19,6\%), no impacts } \\
(2,9 \%), \text { don't know }(5,9 \%)\end{array}$ \\
\hline $\begin{array}{l}\text { Power plants and district heating power stations } \\
(\mathbf{2 0 \% )} \\
\text { households (5,9\%), } \\
\text { industry - commerce - trade (43,3\%), } \\
\text { traffic (26,1\%), don't know (4,7\%) }\end{array}$ \\
\hline
\end{tabular}

Table 9: Study A - Knowledge questions and answers. 